\title{
Metabolic utilization of dietary energy and nutrients for maintenance energy requirements in sows: basis for a net energy system
}

\author{
BY J. NOBLET, X. S. SHI AND S. DUBOIS \\ Institut National de la Recherche Agronomique, Station de Recherches Porcines, \\ 35590 St Gilles, France
}

(Received 7 August $1992-$ Accepted 4 December 1992)

\begin{abstract}
Digestible energy (DE), metabolizable energy (ME) and net energy for maintenance $\left(\mathrm{NE}_{\mathrm{m}}\right)$ values of a set of fourteen diets were measured in six adult sows fed at and below their maintenance energy level. The efficiency of ME for $\mathrm{NE}_{\mathrm{m}}$ was estimated from heat production (HP) measurements (indirect calorimetry) at these different feeding levels. HP was partitioned between HP due to physical activity, thermic effect of food (TEF) and fasting heat production (FHP). The amounts of DE digested in the small intestine or in the hindgut were measured. Equations for prediction of $N E_{m}$ from dietary characteristics were calculated. HP at maintenance level averaged $400 \mathrm{~kJ} / \mathrm{kg}$ body-weight $\mathrm{t}^{0.75}, 16$ and $19 \%$ of the total being due to physical activity and TEF respectively. The efficiency of $\mathrm{ME}$ for $\mathrm{NE}_{\mathrm{m}}$ averaged $77.4 \%$ with higher values for digestible diethyl ether extract $(100 \%)$ and starch + sugar $(82 \%)$. The efficiencies of digestible crude protein $(\mathrm{N} \times 6.25)$ and digestible residue averaged 69 and $56 \%$ respectively. The energy absorbed from the small intestine was used more efficiently than the energy fermented in the hindgut ( $82 \mathrm{v} .59 \%)$. These values are comparable with those obtained in growing pigs. The $\mathrm{NE}_{\mathrm{m}}$ content of diets can be predicted accurately from equations including $\mathrm{DE}$ (or ME) values and some dietary chemical characteristics.
\end{abstract}

Heat production: Maintenance: Net energy: Sow

Evaluation of energy content of feeds for pigs is usually based on their digestible (DE) or metabolizable energy (ME) contents (Agricultural Research Council, 1981; INRA, 1984). But since $\mathrm{ME}$ is used differently according to its composition, energy evaluation systems based on the net energy (NE) concept have also been proposed (Schiemann et al. 1972; Just, 1982; Noblet et al. 1989). These NE systems were established from measurements carried out with growing or fattening pigs. The NE value was, therefore, a combination of NE for maintenance $\left(\mathrm{NE}_{\mathrm{m}}\right)$ and $\mathrm{NE}$ for production (protein and/or fat deposition). However, in pig production a rather large proportion of the consumed feed is almost exclusively used for meeting maintenance energy requirements of the animals (pregnant sows, boars). So far, available scientific information has been insufficient for predicting the $\mathrm{NE}_{\mathrm{m}}$ content of diets or, in other words, proposing relationships between the thermic effect of food (TEF) when fed at maintenance energy level and chemical characteristics of the diet. Breirem (1939) and Close \& Mount (1975) reported a mean TEF equivalent to $20 \%$ of ME content for pigs, which means that the mean efficiency of ME for maintenance $\left(k_{m}\right)$ averages $80 \%$. Comparable results are available in other species; most of the information has been obtained recently with humans from studies concerning the variations of TEF in relation to diet composition (Dauncey, 1979; Dauncey \& Bingham, 1983; Nair et al. 1983; Schutz et al. 1984; Kinabo \& Durnin, 1990). However, in most studies with humans TEF was 
measured over a few hours; therefore, a fraction of the thermogenic effect was ignored (Kinabo \& Durnin, 1990).

The aim of the present experiment was to determine the effect of diet composition on TEF or $k_{m}$ in pigs fed at their maintenance energy level, in order to propose relationships for predicting the $\mathrm{NE}_{\mathrm{m}}$ content of diets and ingredients. The study was based on a set of fourteen diets which were fed to adult sows at and below their energy maintenance requirement. The procedure involved continuous measurement of heat production (HP; indirect calorimetry) and its three main components: fasting heat production (FHP), TEF and energy expenditure due to physical activity. The energy expenditure for thermogenesis was assumed to be negligible since the ambient temperature $\left(24^{\circ}\right)$ was supposed to be within the thermoneutral zone of sows.

\section{MATERIALS AND METHODS}

\section{Experimental design}

Fourteen different diets which differed widely in their chemical composition were fed to six adult Large White sows ( $208 \mathrm{~kg}$ live weight on average). Sows were ovariectomized in order to avoid any effect of cycling and oestrus on heat production measurements. Each sow received eight to ten diets consecutively (eight to ten measurement periods on each animal) and each diet was measured with four different animals. The allocation of animals to diets was arranged in order to obtain similar mean live weights and similar mean measurement period numbers for all diets. Each diet was given for about $28 \mathrm{~d}$, including $17 \mathrm{~d}$ for adaptation and $8 \mathrm{~d}$ in metabolism cages for collection of faeces and urine in order to measure the DE, ME and digestible nutrient contents of diets. Over these $8 \mathrm{~d}$ periods $\mathrm{HP}$ and $\mathrm{CH}_{4}$ production were measured in open-circuit respiration chambers at two different feeding levels: the first $5 \mathrm{~d}$ and the last day at maintenance level (about $400 \mathrm{~kJ} \mathrm{ME} / \mathrm{kg}$ metabolic body weight $\left(\mathrm{BW}^{0.75}\right)$ ) and the other $2 \mathrm{~d}$ at $60 \%$ of this maintenance level. Feeding level of each sow was adjusted at each measurement period in order to keep its body weight and backfat thickness constant over the experiment. The total experiment lasted about 9 months. For each sow FHP was measured four times over the experiment at the end of a balance period. The FHP measurement occurred on the third day after the end of a balance period, the sow being fed at $100 \%$ of its maintenance level for the first $2 \mathrm{~d}$. Sows were fed once daily at 08.30 hours. Therefore, FHP corresponded to HP during the period starting $24 \mathrm{~h}$ after a meal.

The ileal digestibility of energy of the fourteen diets was measured with ileo-rectal anastomosed growing pigs ( $45 \mathrm{~kg}$ live weight on average), in order to differentiate between DE absorbed from the small intestine (DEi) and that at the hindgut level (DEh). The methodological approaches and the results have been described previously (Shi \& Noblet, 1993). The same diets were also given to $45 \mathrm{~kg}$ pigs (Noblet \& Shi, 1993).

\section{Diets and housing}

The fourteen diets were based on wheat, maize starch, cane molasses, soya-bean meal, maize-gluten feed, meat-and-bone meal, rapeseed oil, wheat middlings, sugar-beet pulp, wheat bran and wheat straw (Table 1). All diets contained $(\mathrm{g} / \mathrm{kg}) \mathrm{NaCl} 5, \mathrm{Ca}_{2} \mathrm{PO}_{4} 20$, $\mathrm{CaCO}_{3} 20$, minerals and vitamins mixture 5 (Noblet et al. 1989). The main objective in formulating the diets was to obtain large variations in their chemical characteristics (Table 1). The diets were fed as pellets and the animals had free access to water.

During the balance period, the sows were kept individually in metabolism cages located in $10 \mathrm{~m}^{3}$ respiration chambers. Lighting was given from 08.00 to 20.00 hours. Air velocity 
Table 1. Chemical characteristics of the diets

(Mean values for fourteen diets)

\begin{tabular}{|c|c|c|c|}
\hline & Minimum & Maximum & Mean \\
\hline \multicolumn{4}{|l|}{ Ingredients $(\mathrm{g} / \mathrm{kg})$} \\
\hline Wheat & 0 & $31 \cdot 3$ & $16 \cdot 5$ \\
\hline Maize starch & 0 & $29 \cdot 2$ & $14 \cdot 5$ \\
\hline Wheat straw & 0 & $11 \cdot 2$ & $3 \cdot 7$ \\
\hline Meat-and-bone meal & 0 & 7.9 & $2 \cdot 1$ \\
\hline Rapeseed oil & 0 & $7 \cdot 8$ & $4 \cdot 5$ \\
\hline Cane molasses & 0 & 4.7 & $1 \cdot 7$ \\
\hline Maize-gluten feed & 0 & $13 \cdot 4$ & $6 \cdot 3$ \\
\hline Sugar-beet pulp & 0 & $11 \cdot 8$ & $4 \cdot 7$ \\
\hline Wheat middlings & 0 & 280 & $11 \cdot 6$ \\
\hline Wheat bran & 0 & 17.8 & 6.2 \\
\hline Soya-bean meal & $10 \cdot 2$ & 35.6 & $22 \cdot 4$ \\
\hline \multicolumn{4}{|c|}{ Chemical composition (g/kg DM) } \\
\hline Ash & 79 & 108 & 92 \\
\hline Crude protein $(\mathrm{N} \times 6.25)$ & 159 & 274 & 204 \\
\hline Diethyl ether extract & 16 & 101 & 64 \\
\hline Crude fibre & 37 & 92 & 64 \\
\hline NDF & 118 & 261 & 193 \\
\hline ADF & 45 & 110 & 76 \\
\hline $\mathrm{ADL}$ & 8 & 18 & 13 \\
\hline WICW & 134 & 267 & 210 \\
\hline Starch & 230 & 462 & 358 \\
\hline Sugar & 34 & 81 & 56 \\
\hline Gross energy (MJ/kg DM) & 17.47 & $19 \cdot 23$ & 18.51 \\
\hline
\end{tabular}

* DM, dry matter; NDF, neutral-detergent fibre; ADF, acid-detergent fibre; ADL, acid-detergent lignin; WICW, water-insoluble cell walls.

in the chamber was about $0 \cdot 1 \mathrm{~m} / \mathrm{s}$ and temperature and relative humidity were kept at $24^{\circ}$ and $70 \%$ respectively.

\section{Measurements}

Sows were weighed at the beginning and at the end of the collection period. For each diet and each sow a sample of feed was collected and measured for its dry matter content. Samples of the same diet were subsequently combined for chemical analysis. Faeces and urine were collected daily, stored at $2^{\circ}$, weighed and subsampled at the end of the period. Faeces were freeze-dried for further chemical analysis. $\mathrm{N}$ losses in the air which were recovered in condensed water and outgoing air from the respiration chamber were measured according to the method described by Noblet et al. (1987).

Gas $\left(\mathrm{CO}_{2}, \mathrm{O}_{2}\right.$ and $\left.\mathrm{CH}_{4}\right)$ contents of ingoing and outgoing air were continuously recorded over 7 min intervals during the $8 \mathrm{~d}$ of the excreta collection period. Gas exchanges $\left(\mathrm{O}_{2}, \mathrm{CO}_{2}\right.$ and $\mathrm{CH}_{4}$ ) were calculated for each $7 \mathrm{~min}$ interval according to the method described by Vermorel et al. (1973); values were corrected in order to take into account the changes in gas contents of air in the chamber during the measurement interval. HP was calculated for each interval and over the $24 \mathrm{~h}$ period from gas exchanges according to the formula of Brouwer (1965). Duration of standing was also recorded in the respiration chamber at 7 min intervals by using two i.r. barriers located at the front and the back of the cage. 


\section{Chemical analyses}

Chemical analyses on diets were performed by four different laboratories. The values reported in Table 1 correspond to the mean of the four values. Faeces and urine were analysed by one laboratory. For feed samples the Association of Official Agricultural Chemists (1975) methods were used for measuring moisture, ash, crude protein $(\mathrm{N} \times 6.25$; $\mathrm{CP}$ ), Weende crude fibre (CF) and diethyl ether extract (EE). Gross energy (GE) content was measured using an adiabatic bomb calorimeter. Cell-wall fractions (neutral-detergent fibre (NDF), acid-detergent fibre (ADF), acid-detergent lignin ADL)) were determined according to the methods of Van Soest \& Wine (1967), with previous amylase hydrolysis (Termamyl 300L, Novo Biolabs, Denmark). Water-insoluble cell walls (WICW) were measured according to the method of Carré \& Brillouet (1989). Starch content was estimated from the Ewers polarimetric method (EEC, 1972) and sugar correspond to alcohol-soluble carbohydrates obtained by the method of Luff-Schoorl (Perez, 1991). Similar analyses were carried out on each sample of faeces but EE was measured after $\mathrm{HCl}$ hydrolysis; WICW, starch and sugar contents were not measured. $\mathrm{N}$ in urine, condensed water and outgoing air were determined on fresh material whereas the energy content of urine was obtained after freeze-drying approximately $50 \mathrm{ml}$ in polyethylene bags.

\section{Calculations and statistical analysis}

$\mathrm{DE}, \mathrm{ME}$ and digestible nutrient contents of diets were calculated according to routine procedures (Noblet et al. 1989). ME included energy losses as both urine and methane. Starch and sugar were assumed to be completely digestible. The mean results for the fourteen diets are reported in Table 2.

For each balance period, HP and activity (i.e. percentage of time while standing) were measured simultaneously at $7 \mathrm{~min}$ intervals over $24 \mathrm{~h}$ after the morning meal and during five consecutive days at maintenance level. These findings (about 1000 values for one sow given one diet) were included in a regression model where HP was related to time after the beginning of the meal and activity. The best model was a linear one where the coefficient attributed to activity corresponded to the mean energy expenditure while standing, so called activity HP (AHP). A typical activity and HP daily pattern recorded on one sow is given in Fig. 1. Differences between animals were due to the level of activity occurring after the inevitable meal activity. In addition, AHP $(\mathrm{kJ} / \mathrm{min}$ standing activity) was particularly constant for each sow over the total experiment (Noblet et al. 1993). Total mean AHP over $24 \mathrm{~h}(\mathrm{MJ} / \mathrm{d})$ of each $5 \mathrm{~d}$ period was obtained by multiplying the total duration of activity by the mean energy cost obtained from the regression equation. Resting HP (RHP; MJ/d) was then calculated as the difference between total HP and AHP. The mean values of daily AHP and RHP obtained for each sow over the total experiment are given in Table 3. RHP during the $2 \mathrm{~d}$ at the low feeding level ( $60 \%$ of maintenance level) was similarly calculated; the coefficient used for estimating AHP was the value obtained from the regression calculated over the previous $5 \mathrm{~d}$ at maintenance level. A more comprehensive description of the approach has been reported by Noblet et al. (1993).

Three different methods were used to estimate FHP. The first one involved measurement of RHP during $1 \mathrm{~d}$ the sow did not receive any food in the morning. The second method resulted from the regression equation between RHP at high (mean of $5 \mathrm{~d}$ at $100 \%$ maintenance level) and at low (second day at $60 \%$ of maintenance) feeding levels and corresponding $\mathrm{ME}$ intakes $(\mathrm{MJ} / \mathrm{d}$ ). The first day at the low feeding level was supposed to be an adaptation day. ME intake considered in the regression (MEc) was equivalent to actual ME intake minus AHP, since a proportion of dietary energy (equal to AHP) was lost directly for activity energy requirements. The regression was calculated for each sow, the 
Table 2. Digestible nutrients and energy values of diets*

(Mean values for fourteen diets)

\begin{tabular}{|c|c|c|c|}
\hline & Minimum & Maximum & Mean \\
\hline Body wt (kg) & 195 & 227 & 208 \\
\hline Dry matter $(\mathrm{DM})$ intake $(\mathrm{g} / \mathrm{d})^{*}$ & 1394 & 1770 & 1580 \\
\hline \multicolumn{4}{|l|}{ Digestible nutrients (g/kg DM) } \\
\hline Dry matter & 762 & 871 & 821 \\
\hline Organic matter & 725 & 833 & 787 \\
\hline Crude protein $(\mathrm{N} \times 6.25)$ & 134 & 239 & 175 \\
\hline Diethyl ether extract & $5 \cdot 3$ & $78 \cdot 7$ & $47 \cdot 3$ \\
\hline Crude fibre & 26 & 55 & 40 \\
\hline NDF & 89 & 176 & 135 \\
\hline ADF & 30 & 64 & 45 \\
\hline Residue $\dagger$ & 105 & 219 & 151 \\
\hline $\mathrm{ME} / \mathrm{DE}(\%)$ & $89 \cdot 3$ & 93.7 & $92 \cdot 3$ \\
\hline \multicolumn{4}{|l|}{ Energy $(\mathrm{MJ} / \mathrm{kg} \mathrm{DM})$ as: } \\
\hline Methane & $0 \cdot 16$ & $0 \cdot 31$ & 0.21 \\
\hline Urine & 0.78 & $1 \cdot 33$ & 0.99 \\
\hline \multicolumn{4}{|l|}{ Energy values (MJ/kg DM) } \\
\hline Faecal DE & $13 \cdot 85$ & $17 \cdot 01$ & 15.62 \\
\hline Ileal DE & $9 \cdot 67$ & 13.63 & 11.79 \\
\hline Hindgut DE & 2.67 & $5 \cdot 67$ & 3.84 \\
\hline $\mathrm{ME}$ & $12 \cdot 87$ & $15 \cdot 74$ & $14 \cdot 43$ \\
\hline $\mathrm{NE}_{\mathrm{m}}$ & 9.66 & 12.59 & $11 \cdot 61$ \\
\hline$k_{m 1}\left(\mathrm{NE}_{\mathrm{m}} / \mathrm{DE} ; \%\right)$ & $66 \cdot 0$ & 74.6 & $71 \cdot 4$ \\
\hline$k_{m}\left(\mathrm{NE}_{\mathrm{m}} / \mathrm{ME} ; \%\right)$ & $73 \cdot 9$ & $80 \cdot 7$ & $77 \cdot 4$ \\
\hline Respiratory quotient* & 0.86 & 0.91 & 0.88 \\
\hline
\end{tabular}

NDF, neutral-detergent fibre; $\mathrm{ADF}$, acid-detergent fibre; $\mathrm{ME}$, metabolizable energy; DE, digestible energy; $\mathrm{NE}_{\mathrm{m}}$, net energy for maintenance; $k_{m}$, the efficiency of $\mathrm{ME}$ intake for maintenance requirements; $k_{m 1}$, the efficiency of DE intake for maintenance requirements.

* At maintenance feeding level.

$\uparrow$ Residue = digestible organic matter - (digestible crude protein + digestible diethyl ether extract + starch + sugar).

number of observations varying between sixteen and twenty (i.e. eight to ten diets). The extrapolation to zero energy intake provided an estimate of FHP. The third method was comparable with the second one but the analysis was carried out on data from all sows. In this covariance model the covariate was the variable (MEc) involved in the regression model of method 2 and the main factor was the animal $(n 6)$. FHP of each sow was obtained as the difference between adjusted HP and HP associated to MEc intake, this latter value being estimated from the slope of the covariate. Body weight and body condition (backfat thickness) of each sow were kept constant over the total experiment by adjusting feed intake. Subsequently, FHP was supposed to be constant for each sow over the 9 months of the experiment.

The TEF was estimated as the difference between RHP at the maintenance level and FHP. NE intake (MJ/d) was calculated as MEc intake $(\mathrm{MJ} / \mathrm{d})$ minus TEF $(\mathrm{MJ} / \mathrm{d})$. The efficiency of $\mathrm{ME}$ intake for maintenance requirements $\left(k_{m}\right)$ was equivalent to the ratio $(\times 100)$ between $\mathrm{NE}$ and $\mathrm{MEc} . \mathrm{NE}_{\mathrm{m}}(\mathrm{MJ} / \mathrm{kg}$ dry matter $)$ was calculated as ME content multiplied by $k_{m}(/ 100)$. These calculations were carried out on each balance period $(n 56)$. The final $\mathrm{DE}, \mathrm{ME}$ and $\mathrm{NE}_{\mathrm{m}}$ values of each diet corresponded to the mean of the four measurements carried out on each diet.

The effect of sow on HP and its main components were submitted to analysis of variance 


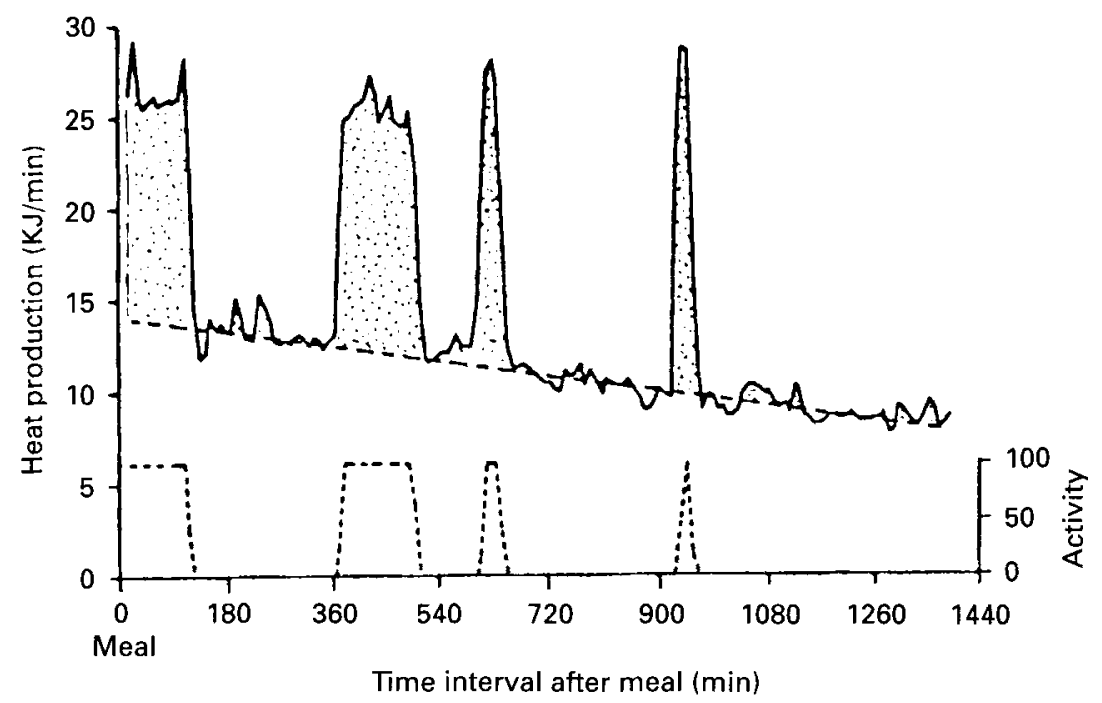

Fig. 1. Effect of time-interval after the meal (min) and physical activity (percentage of time while standing for each 7 min measurement interval; --) on heat production (-) of a sow when fed at maintenance energy level (from Noblet et al. 1993).

with sow ( $n$ 6) and diet ( $n$ 14) as the main effects (Table 3 ). Regression equations were calculated in order to predict the $\mathrm{NE}_{\mathrm{m}}$ content of diets from either digestible nutrient contents (Table 5) or from DE or ME contents and chemical characteristics (Table 6). Regression equations were also calculated in order to analyse the effect of diet composition on $k_{m}$. Formulation of diets was such that low correlation coefficients between variables involved in the regression equations were expected, in order to improve the accuracy and the validity of the prediction (Table 4). $\mathrm{NE}_{\mathrm{m}}$ was also related to DEi and DEh. SAS (1988) was used for all statistical analyses.

RESULTS AND DISCUSSION

\section{Estimation of fasting heat production}

In the present experiment three approaches were used to estimate FHP. In the first method HP was measured in sows from 24 to $48 \mathrm{~h}$ after a meal. Under such conditions RHP declined regularly over the $24 \mathrm{~h}$ period with a significant $\mathrm{CH}_{4}$ production, even $48 \mathrm{~h}$ after the last meal. In other words the digestion of the last meal (mainly at the hindgut level) was not completed over the day of FHP measurement. Therefore, HP included energy expenditure from the digestive and metabolic utilization of dietary energy. Consequently, the mean RHP recorded over the $24 \mathrm{~h}$ period was $15.47 \mathrm{MJ} / \mathrm{d}$ whereas the mean RHP over the last $6 \mathrm{~h}$ of the $24 \mathrm{~h}$ starvation period (or $42-48 \mathrm{~h}$ after the last meal) averaged $14.24 \mathrm{MJ} / \mathrm{d}$ for the six sows.

In the two other methods FHP was obtained either by regression (on each sow) or by covariance (on all sows) techniques with extrapolation to zero feed intake. Estimates of FHP obtained for each sow from the two statistical models were similar, the slope of the variable or the covariate being in all situations close to $0.23(0.229 \mathrm{SD} 0.016$ in the covariance model). In addition, the values of FHP obtained by the extrapolation approach $(14.56 \mathrm{MJ} / \mathrm{d}$, on average; Table 3) were close to what was measured during the last $6 \mathrm{~h}$ of the fasting day $(14.24 \mathrm{MJ} / \mathrm{d})$ but lower than RHP recorded from 24 to $48 \mathrm{~h}$ after a meal $(15 \cdot 47 \mathrm{MJ} / \mathrm{d})$. 
Table 3. Body weight $(B W)$, dry matter $(D M)$ intake metabolizable energy $(M E)$ intake and heat production of sows at maintenance feeding level*

(Mean values for fourteen diets and four sows per diet)

\begin{tabular}{|c|c|c|c|c|c|c|c|}
\hline \multirow[b]{2}{*}{ Sow } & \multirow{2}{*}{$\begin{array}{l}\text { BW } \\
(\mathrm{kg})\end{array}$} & \multirow{2}{*}{$\begin{array}{c}\mathrm{DM} \\
\text { intake } \\
(\mathrm{g} / \mathrm{d})\end{array}$} & \multirow{2}{*}{$\begin{array}{c}\mathrm{ME} \\
\text { intake } \\
(\mathrm{MJ} / \mathrm{d})\end{array}$} & \multicolumn{4}{|c|}{ Heat production $(\mathrm{MJ} / \mathrm{d}) \ddagger$} \\
\hline & & & & AHP & RHP & FHP & TEF \\
\hline A & $175^{\mathrm{f}}$ & $1430^{\prime:}$ & $20.84^{c}$ & $4 \cdot 41^{a}$ & $15 \cdot 93^{\circ}$ & $12 \cdot 21$ & $3 \cdot 71^{\mathrm{b}}$ \\
\hline B & $191^{\mathrm{e}}$ & $1477^{\circ}$ & $21 \cdot 11^{\mathrm{c}}$ & $4 \cdot 46^{:}$ & $16 \cdot 87^{\mathrm{d}}$ & $13 \cdot 22$ & $3.65^{b}$ \\
\hline $\mathrm{C}$ & $210^{\mathrm{d}}$ & $1588^{\circ}$ & $22 \cdot 78^{\mathrm{b}}$ & $1.53^{\mathrm{e}}$ & $19 \cdot 44^{\mathrm{b}}$ & 14.65 & $4.79^{a}$ \\
\hline $\mathrm{D}$ & $216^{\circ}$ & $1614^{\mathrm{b}}$ & $23 \cdot 07^{\mathrm{b}}$ & $3.88^{\mathrm{ab}}$ & $19 \cdot 11^{\mathrm{an}}$ & $14 \cdot 35$ & $4 \cdot 76^{\mathrm{a}}$ \\
\hline $\mathbf{E}$ & $226^{\mathrm{b}}$ & $1683^{a}$ & $24 \cdot 65^{\mathrm{a}}$ & $3 \cdot 42^{\text {be }}$ & $19 \cdot 00^{\mathrm{b}}$ & $14 \cdot 90$ & $4 \cdot 10^{a b}$ \\
\hline $\mathrm{F}$ & $232^{\mathrm{a}}$ & $1691^{\mathrm{a}}$ & $24 \cdot 69^{\mathrm{a}}$ & $2 \cdot 53^{\mathrm{d}}$ & $21 \cdot 34^{\mathrm{a}}$ & $16 \cdot 70$ & $4 \cdot 64^{\mathrm{a}}$ \\
\hline Mean & 208 & 1580 & 22.74 & $3 \cdot 34$ & 18.64 & $14 \cdot 36$ & $4 \cdot 27$ \\
\hline RSD & 4 & 46 & 0.97 & 0.93 & 0.97 & & $0 \cdot 81$ \\
\hline
\end{tabular}

RSD, residual SD; AHP, activity heat production; RHP, resting heat production; FHP, fasting heat production; TEF, thermic effect of food.

* For details of diets, see Tables 1 and 2 and p. 408.

$\dagger$ Least square means from the analysis of variance with diet ( $n$ 14) and sow $(n 6)$ as the main effects; the effect of sow was significant $(P<0.01)$ for all criteria. ${ }^{a}, \mathrm{~b}, c, \mathrm{~d}, \mathrm{e}, \mathrm{f}$ Within each column mean values with the same superscript letter were not significantly different $(P>0.05)$

¥ For details of calculation of the different components of heat production, see pp. 411-412.

The reduction of RHP over the fasting day is consistent with previous observations of Close \& Mount (1975) in growing pigs whose metabolic rate continued to decrease over $3-4 \mathrm{~d}$ of fasting. This effect might be more important in adult sows whose hindgut is more developed and where digestion of diet is more prolonged. Consequently, even though FHP estimates obtained during the last part of the fasting day were close to the values obtained by the extrapolation methods, TEF and $\mathrm{NE}_{\mathrm{m}}$ values were calculated from the latter estimates (mean of regression and covariance values; Table 3).

In human energy metabolism studies TEF is usually estimated as the difference between cumulated HP over a few hours after a meal and HP after an overnight fast (equivalent to FHP). But, in most studies, the duration of measurement after the meal is short, so that HP at the end of the measurement period is higher than the FHP value. Consequently, TEF is underestimated (Kinabo \& Durnin, 1990). Therefore, TEF should be measured over longer periods, with subsequent higher values for TEF (Schutz et al. 1984). In addition, the present study shows that, for sows, FHP measured under such experimental conditions is higher than minimal HP obtained after a prolonged fasting. Furthermore, factors such as the previous feeding level (Koong et al. 1982), level of activity or ambient temperature affect FHP values. These different observations mean that estimates of TEF are very dependent on the experimental procedure and the method used for estimating FHP.

The daily FHP at zero activity differed between sows (Table 3 ). When expressed per unit $\mathrm{BW}^{0.75}$, the variation was smaller (range $254-280 \mathrm{~kJ} / \mathrm{kg} \mathrm{BW}^{0.75}$ ) with a mean value equivalent to $261 \mathrm{~kJ} / \mathrm{kg} \mathrm{BW}{ }^{075}$. Since the mean TEF averaged $22.6 \%$ of ME intake $\left(k_{m}\right.$ in Table 2$)$, the mean ME requirement for maintenance at zero activity level was $337 \mathrm{~kJ} / \mathrm{kg} \mathrm{BW}^{0.75}$. As reported in Table 3, the mean daily activity $\mathrm{HP}$ was $3.34 \mathrm{MJ} / \mathrm{d}$, for a mean duration of standing activity of $241 \mathrm{~min}$ (Noblet et al. 1993). This quantity was equivalent to $68 \mathrm{~kJ} / \mathrm{kg} \mathrm{BW^{0.75 }}$, on average. Therefore, the total $\mathrm{ME}$ requirement for maintenance $\left(\mathrm{ME}_{\mathrm{m}}\right)$ of the six sows used in the present experiment averaged $400 \mathrm{~kJ} / \mathrm{kg}$ $\mathrm{BW}^{0.75}, 16$ and $19 \%$ of the requirement being associated with physical activity and TEF 
Table 4. Correlation coefficients between energy values and digestible nutrient contents of the experimental diets for sows ${ }^{*}$

(Mean values for fourteen diets)

\begin{tabular}{lcccccc}
\hline & $\mathrm{DE}$ & $\mathrm{ME}$ & $\mathrm{NE}_{\mathrm{m}}$ & $\mathrm{DCP}$ & $\mathrm{DEE}$ & CHO \\
\hline $\mathrm{ME}$ & 0.98 & - & - & - & - & - \\
$\mathrm{NE}$ & 0.92 & 0.95 & - & - & - & - \\
$\mathrm{DCP}$ & 0.45 & 0.31 & 0.12 & - & - & - \\
$\mathrm{DEE}$ & 0.51 & 0.52 & 0.61 & -0.08 & - & - \\
$\mathrm{CHO}$ & -0.22 & 0.35 & 0.35 & -0.35 & -0.33 & - \\
Dres & -0.43 & -0.58 & -0.57 & 0.19 & -0.07 & -0.82 \\
\hline
\end{tabular}

$\mathrm{DE}$, digestible energy; $\mathrm{ME}$, metabolizable energy; $\mathrm{NE}_{\mathrm{m}}$, net energy for maintenance; $\mathrm{DCP}$, digestible crude protein $(\mathrm{N} \times 6.25)$; DEE, digestible diethyl ether extract; $\mathrm{CHO}$, starch + sugar; Dres, digestible residue (digestible organic matter $-(\mathrm{DCP}+\mathrm{DEE}+\mathrm{CHO})$ ).

* For details of diets, see Tables 1 and 2 and p. 408.

$\dagger$ Correlation coefficient whose absolute value was higher than 0.52 and 0.66 was significantly different from zero at the $P<0.05$ and $P<0.01$ levels respectively.

respectively. The value obtained for $\mathrm{ME}_{\mathrm{m}}$ of sows is comparable with estimates reported by Close et al. (1985) and Noblet et al. (1990) in pregnant sows.

Energy balance data (Tables 2 and 4) show that in sows fed at their maintenance level, energy losses in faeces, urine and methane represented about $15 \cdot 3,5 \cdot 3$ and $1 \cdot 1 \%$ of the gross energy intake respectively. Since ME supply was slightly higher than requirements for maintenance, energy balance was positive and represented $2.6 \%$ of gross energy intake. Total heat production, equivalent to $75.6 \%$ of gross energy intake, had different origins: $49.4,14.7$ and $11.5 \%$ of gross energy intake were associated with fasting heat production, thermic effect of food and physical activity, respectively. The partition of gross energy intake in sows kept on a maintenance situation is illustrated in Fig. 2.

Effect of diet composition on TEF or efficiency of utilization of ME for maintenance $k_{m}$ averaged $77 \cdot 4 \%$ for the fourteen diets $\left(k_{m}\right.$ in Table 2$)$. This means that $22.6 \%$ of ME intake was lost as HP during digestive and metabolic utilization of energy. $\mathrm{NE}_{\mathrm{m}}$, expressed as a percentage of DE, averaged $71.6 \%\left(k_{m 1}\right.$ in Table 2$)$. In connection with methodological differences, these values are lower than those obtained with humans where TEF represents about 10\% of energy intake (Dauncey, 1979; Golay et al. 1983). On the other hand, they are close to those reported by Breirem (1939) and Close \& Mount (1975) in pigs, the highest $k_{m}$ values obtained in the present study with high-energy diets being identical $(80 \%)$ to the value obtained by these authors.

As indicated in Table $2, k_{m}$ ranged between 74 and $81 \%$. Regression analysis showed that $k_{m}$ increased when starch and fat (EE) or digestible diethyl ether extract (DEE) contents $(\mathrm{g} / \mathrm{kg}$ dry matter) of diets were increased. The following relationships were obtained:

$$
\begin{aligned}
k_{m}= & 67.2+0.066 \times \mathrm{EE}+0.016 \times \operatorname{starch}\left(R^{2} 0.57 ; \text { residual SD }(\mathrm{RSD}) 1 \cdot 9\right), \\
& k_{m}=67.9+0.079 \times \mathrm{DEE}+0.016 \times \operatorname{starch}\left(R^{2} 0.60 ; \mathrm{RSD} 1 \cdot 6\right)
\end{aligned}
$$

Corresponding equations for $k_{m 1}$ were:

$$
\begin{gathered}
k_{m 1}=57.3+0.076 \times \mathrm{EE}+0.026 \times \operatorname{starch}\left(R^{2} 0.70 ; \operatorname{RSD} 1 \cdot 6\right), \\
k_{m 1}=58.1+0.091 \times \mathrm{DEE}+0.025 \times \operatorname{starch}\left(R^{2} 0.73 ; \operatorname{RSD} 1 \cdot 6\right) .
\end{gathered}
$$




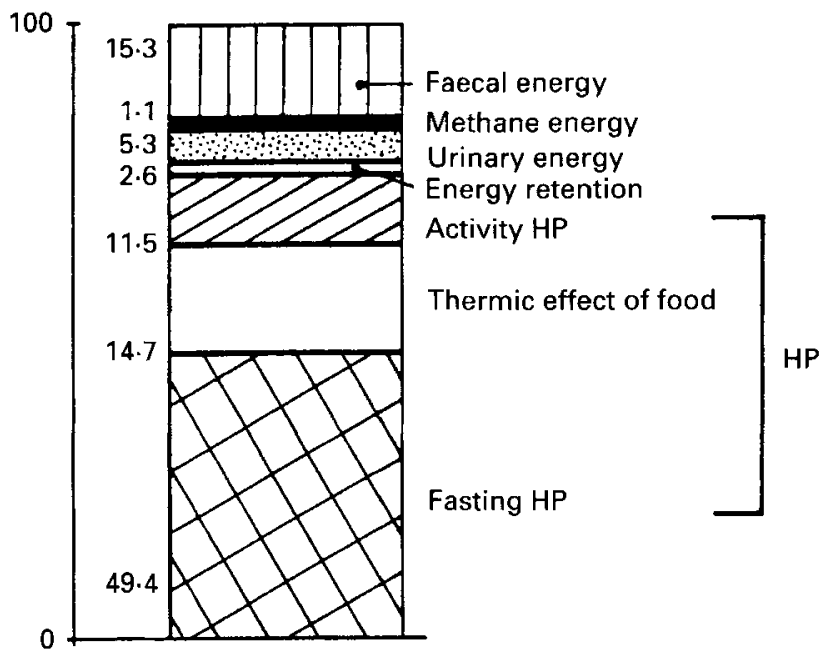

Fig. 2. Partition of gross energy intake between energy retained and energy losses in faeces, urine, methane and different components of heat production (HP), in adult sows when fed at their maintenance energy level (mean of fifty-six measurements from six different sows).

The coefficients obtained in both groups of equations indicate a higher positive effect of fat than of starch, even when expressed per unit energy. In addition, these relationships demonstrate that $k_{m}$ was higher for fat or starch than for the other dietary nutrients whose efficiency averaged the intercept value (about 68\%). This is confirmed by equations reported in Table 5. In order to calculate the efficiencies of digestible nutrients for $\mathrm{NE}_{\mathrm{m}}$, the intercept of these equations was forced to zero.

Different fractionation methods of digestible organic matter were tested, all including digestible CP (DCP) and DEE. Especially for NE, the accuracy of the prediction was not improved when the different digestible fibre estimates (digestible CF, digestible NDF, etc.) were considered. The best linear model was the combination of DCP, DEE, starch + sugar (CHO) and the digestible residue (Dres) equivalent to digestible organic matter $\left(\mathrm{DCP}+\mathrm{DEE}+\mathrm{CHO}\right.$ ) (Table 5). In the $\mathrm{DE}, \mathrm{ME}$ and $\mathrm{NE}_{\mathrm{m}}$ equations calculated according to this model the intercept was not significantly different from zero $(P>0.05)$. The efficiencies of digestible nutrients for $\mathrm{NE}_{\mathrm{m}}$ were calculated for each nutrient as the ratio, coefficient obtained in the NE equation: corresponding coefficient in the $\mathrm{ME}\left(k_{m}\right)$ or $\mathrm{DE}$ $\left(k_{m 1}\right)$ equations.

First, the comparison of the coefficients obtained in the ME and DE equations indicated that the energy losses during the DE to ME step concerned DCP and Dres, corresponding schematically to energy losses in the urine and as $\mathrm{CH}_{4}$ respectively. Second, during the ME to NE step the equations show that TEF was the highest for Dres $(44 \%$ of $\mathrm{ME}$ intake) and the lowest (about zero) for DEE. The values for $\mathrm{CHO}$ (equivalent to carbohydrates degraded in the small intestine and producing mainly glucose) and DCP were intermediate ( 18 and $31 \%$ respectively). The value obtained for DEE is rather surprising. However, it must be noted that calculated TEF of ME or nutrients corresponds to TEF when ME or dietary nutrients replace body reserves mobilization (mainly fat) when animals are fed below their maintenance level. Therefore, $k_{m}$ represents an apparent efficiency. It is then logical to obtain a negligible TEF for DEE since the energy cost of utilization of fat (or the amount of ATP that is released) is expected to be the same for DEE and mobilized body fat. In addition, we showed previously (Noblet \& Shi, 1993) that the 
Table 5. Prediction of digestible energy $(D E)$, metabolizable energy $(M E)$ and net energy for maintenance $\left(N E_{m}\right)(M J / k g$ dry matter) from digestible nutrient contents $(\mathrm{g} / \mathrm{kg}$ dry matter) of fourteen experimental diets for sows*

(Linear model without intercept)

\begin{tabular}{|c|c|c|c|c|c|c|}
\hline \multirow{2}{*}{\multicolumn{2}{|c|}{ Digestible nutrient ... }} & \multicolumn{4}{|c|}{ Regression coefficients } & \multirow{3}{*}{$\frac{\begin{array}{c}\text { Residual } \\
\text { SD }\end{array}}{0.06}$} \\
\hline & & \multirow{3}{*}{$\begin{array}{c}\text { DCP } \\
0.0237 \\
0.0005\end{array}$} & \multirow{3}{*}{$\begin{array}{c}\text { DEE } \\
0.0382 \\
0.0006\end{array}$} & \multirow{2}{*}{$\frac{\mathrm{CHO}}{0.0172}$} & \multirow{3}{*}{$\begin{array}{c}\text { Dres } \\
0.0171 \\
0.0004\end{array}$} & \\
\hline DE & Mean & & & & & \\
\hline & SD & & & 0.0001 & & \\
\hline \multirow[t]{2}{*}{$\mathrm{ME}$} & Mean & 0.0207 & 0.0378 & 0.0169 & 0.0132 & 0.08 \\
\hline & SD & 0.0006 & 0.0009 & 0.0002 & 0.0006 & \\
\hline \multirow{2}{*}{$\mathrm{NE}_{\mathrm{m}}$} & Mean & 0.0142 & 0.0384 & 0.0139 & 0.0074 & $0 \cdot 26$ \\
\hline & $\mathrm{SD}$ & 0.0021 & 0.0028 & 0.0006 & 0.0020 & \\
\hline \multirow{2}{*}{\multicolumn{2}{|c|}{$\begin{array}{l}k_{m \mathbf{1}}(\mathrm{NE} / \mathrm{DE} ; \%) \dagger \\
k_{m}(\mathrm{NE} / \mathrm{ME} ; \%) \dagger\end{array}$}} & 60 & 100 & 81 & 43 & \\
\hline & & 69 & 102 & 82 & 56 & \\
\hline
\end{tabular}

DCP, digestible crude protein $(\mathrm{N} \times 6.25)$; DEE, digestible diethyl ether extract; $\mathrm{CHO}$, starch + sugar; Dres, digestible residue (digestible organic matter $-(\mathrm{DCP}+\mathrm{DEE}+\mathrm{CHO})$ ); $k_{m 1}$, efficiency of DE intake for maintenance requirements; $k_{m}$, efficiency of $\mathrm{ME}$ intake for maintenance requirements.

* For details of experimental diets, see Tables 1 and 2 and p. 408.

$\dagger$ Calculated as the ratio $(\times 100)$ between coefficients within the same column.

amount of EE actually absorbed before the end of the ileum was slightly higher than the measured DEE content at the faecal level. Indeed, this latter quantity represented an apparent value and included endogenous production of fat at the hindgut level.

On theoretical considerations (Armstrong, 1969), the TEF of infused glucose should be close to zero. The difference with the value obtained in the present study is partly explained by the fact that intake of starch (and sugar) involved additional energy cost for prehension, mastication, digestion and absorption that would reduce the apparent efficiency of utilization of CHO for maintenance. With regard to DCP, the theoretical $k_{m}$ value is about $80 \%$ (Armstrong, 1969), which is again higher than the observed value in the present experiment $(69 \%)$. The discrepancy can be related to the same reasons as for CHO. Finally, the $k_{m}$ value obtained for Dres $(56 \%)$ is also lower than the theoretical one $(80-85 \%$, according to Armstrong, 1969), the difference being consistent with the additional energy costs associated with the consumption of fibre.

The lower efficiency of Dres than for $\mathrm{CHO}$ is related to the nature of nutrients absorbed which are predominantly volatile fatty acids and glucose respectively. In the present experiment, DEi and DEh were estimated. Therefore, it was possible to relate $\mathrm{ME}$ and $\mathrm{NE}_{\mathrm{m}}$ to DEi and DEh; the following relationships were obtained:

$$
\begin{aligned}
& \mathrm{ME}=0.97(\mathrm{SD} 0.01) \times \mathrm{DEi}+0.79(\mathrm{SD} 0.02) \times \mathrm{DEh}(\mathrm{RSD} 0.10), \\
& \mathrm{NE}_{\mathrm{m}}=0.80(\mathrm{SD} 0.03) \times \mathrm{DEi}+0.46(\mathrm{SD} 0.08) \times \mathrm{DEh}(\operatorname{RSD} 0.35),
\end{aligned}
$$

where energy values are expressed as $\mathrm{MJ}$ per $\mathrm{kg}$ dry matter. These equations indicate that the efficiencies of $\mathrm{ME}$ for $\mathrm{NE}_{\mathrm{m}}$ were 82 and $59 \%$ when energy was degraded in the small intestine and in the hindgut respectively. The latter value is consistent with the efficiency of Dres for $\mathrm{NE}_{\mathrm{m}}(56 \%)$ while the first one corresponds to the combination of efficiencies of nutrients digested at the small intestine level (DCP, DEE and CHO).

Comparable information on utilization of $\mathrm{ME}$ and digestible nutrients for $\mathrm{NE}_{\mathrm{m}}$ in the literature are scarce. However, the present findings are consistent with most results 
Table 6. Prediction of net energy for maintenance $\left(N E_{m}\right)$ content of fourteen experimental diets for sows* $(M J / k g$ dry matter $(D M))$ from digestible energy $(D E)$ or metabolizable energy (ME) contents $(M J / k g D M)$ and/or chemical characteristics $(\mathrm{g} / \mathrm{kg} \mathrm{DM})^{*}$

\begin{tabular}{clcc}
$\begin{array}{c}\text { Equation } \\
\text { no. }\end{array}$ & \multicolumn{2}{c}{$\begin{array}{c}\text { Residual } \\
\text { SD }\end{array}$} \\
1 & $\mathrm{NE}_{\mathrm{m}}=-4.45+1.128 \times \mathrm{DE}-0.0098 \times \mathrm{CP}$ & 0.95 & 0.22 \\
2 & $\mathrm{NE}_{\mathrm{m}}=-7.30+1.299 \times \mathrm{ME}-0.0053 \times \mathrm{CP}+0.0125 \times \mathrm{CF}$ & 0.97 & 0.18 \\
3 & $\mathrm{NE}_{\mathrm{m}}=-7 \cdot 13+1.291 \times \mathrm{ME}-0.0054 \times \mathrm{CP}+0.0101 \times \mathrm{ADF}$ & 0.97 & 0.19 \\
4 & $\mathrm{NE}_{\mathrm{m}}=14.74-0.0283 \times \mathrm{Ash}+0.0206 \times \mathrm{EE}-0.0120 \times \mathrm{NDF}$ & 0.90 & 0.33 \\
\hline
\end{tabular}

$\mathrm{CP}$, crude protein $(\mathrm{N} \times 6.25)$; $\mathrm{CF}$; Weende crude fibre; EE, diethyl ether extract; $\mathrm{ADF}$, acid-detergent fibre; NDF, neutral-detergent fibre.

* For details of experimental diets, see Tables 1 and 2 and p. 408.

obtained with humans or rats, reporting a higher TEF for protein than for carbohydrates (Dauncey \& Bingham, 1983; Nair et al. 1983), the TEF of fat usually being lower than that for carbohydrates (Lin et al. 1979; Hurni et al. 1982). In addition, the extent of TEF measured in these studies is usually lower (less than $15 \%$ of energy intake) than has been reported with domestic animals (Van Es et al. 1984; present study). This difference is partly due to the methods used for estimating BMR or FHP and TEF (see pp. 411-412).

Approaches comparable to that used in the present study have been applied in growing pigs, the efficiency $(k)$ then corresponding to the combination of efficiencies for maintenance and for energy deposition (Schiemann et al. 1972; Just, 1982; Noblet et al. 1989). The $k$ values in $45 \mathrm{~kg}$ growing pigs obtained by Noblet et al. (1989) in the same conditions as in the present study were $54,94,83$ and $56 \%$ for DCP, DEE, CHO and Dres respectively. The comparison of both sets of data indicates a hierarchy between digestible nutrients which is comparable when they are used either for maintenance or for maintenance + growth. However, the efficiencies of ME from DCP or DEE would be higher when they are used for maintenance only, resulting in a slightly higher overall efficiency of dietary $\mathrm{ME}$ for $\mathrm{NE}_{\mathrm{m}}$ (77.4\%; Table 2) than for maintenance + growth: $74 \%$ according to equations proposed by Noblet et al. (1989) or to direct measurements on this set of diets (J. Noblet, X. S. Shi and S. Dubois, unpublished results).

\section{Prediction of NE content of diets for maintenance}

For practical purposes, it is important to predict the NE content of feeds (ingredients or diets) in order to establish a hierarchy between feeds and adapt feed supply to energy requirements of animals. Therefore, prediction equations for $\mathrm{NE}_{\mathrm{m}}$ were established. Similar to the report by Noblet et al. (1989) for growing pigs, $\mathrm{NE}_{\mathrm{m}}$ can be estimated from a linear combination of digestible nutrient contents (Table 5), from DE (or ME) and some chemical characteristics or directly from dietary chemical characteristics (Table 6).

The accuracy of the models including DE (or ME) value was higher than the best model based on digestible nutrient contents $(0 \cdot 18-0 \cdot 22 v .0 \cdot 26 \mathrm{MJ} / \mathrm{kg}$ dry matter for RSD). The prediction equation based on crude nutrient contents only had the lowest accuracy $(0 \cdot 33$ for RSD). In all the equations including DE (or $\mathrm{ME}$ ), $\mathrm{CP}$ content affected negatively the $\mathrm{NE}_{\mathrm{m}}$ value. This should be related to the lower efficiency of $\mathrm{DCP}$ for $\mathrm{NE}_{\mathrm{m}}$; the low efficiency of Dres for $\mathrm{NE}_{\mathrm{m}}$ was included in the negative intercept. In the equations with $\mathrm{ME}$ content the prediction was further improved when the fibre content (CF or ADF) was considered. The 
biological interpretation of the positive value of the coefficient for CF or ADF is difficult; the result is probably related to the high negative value of the intercept.

\section{Conclusion}

The present study indicates that the efficiency of ME for meeting the maintenance energy requirements of pigs averaged $77 \%$ and was reduced when the DCP or the fibre contents were increased. On the other hand, it was increased when more carbohydrates (starch) or fat were included in the diet. Similar results were obtained in growing pigs when ME was used for both maintenance and production. Equations for prediction of NE for maintenance from DE or ME values and chemical characteristics are proposed.

The authors gratefully acknowledge Sylviane Barre, Y. Lebreton, Nadine Mézière and A. Roger for their technical assistance.

\section{REFERENCES}

Agricultural Research Council (1981). The Nutrient Requirements of Pigs. Slough: Commonwealth Agriculture Bureaux.

Armstrong, D. G. (1969). Cell bioenergetics and energy metabolism. In Handbuch der Tierernährung, pp. 385-414 [W. Lenkeit, K. Breirem and E. Craseman, editors]. Hamburg und Berlin: Verlag P. Parey.

Association of Official Agricultural Chemists (1975). Official Methods of Analysis, 12th ed. Washington, DC: AOAC.

Breirem, K. (1939). Der energieumsatz bei den schweinen (Energy utilization in pigs). Tierernährung 11, 487-528.

Brouwer, E. (1965). Report of sub-committee on constants and factors. In Energy Metabolism. European Association of Animal Production Publication no. 11, pp. 441-443 [K. L. Blaxter, editor]. London: Academic Press.

Carré, B. \& Brillouet, J. M. (1989). Determination of water-insoluble cell walls in feeds. Interlaboratory study. Journal of the Association of Official Analytical Chemists 72, 463-467.

Close, W. H. \& Mount, L. E. (1975). The rate of heat loss during fasting in the growing pig. British Journal of Nutrition 34, 279-290.

Close, W. H., Noblet, J. \& Heavens, R. P. (1985). Studies on energy metabolism of the pregnant sow. 2. The partition and utilization of metabolizable energy intake in pregnant and non-pregnant animals. British Journal of Nutrition 53, 267-279.

Dauncey, M. J. (1979). Energy metabolism in man and the influence of diet and temperature: a review. Journal of Human Nutrition 33, 259-269.

Dauncey, M. J. \& Bingham, S. A. (1983). Dependence of 24 h energy expenditure in man on the composition of the nutrient intake. British Journal of Nutrition 52, 429-442.

EEC (1972). Analytical determination of starch. Official Journal of European Communities L123/7.

Golay, A., Schutz, Y., Broquet, C., Moeri, R., Felber, J. P. \& Jéquier, E. (1983). Decreased thermogenic response to an oral glucose load in older subjects. Journal of the American Geriatrics Society 31, 144-148.

Hurni, M., Burnand, B., Pittet, Ph. \& Jequier, E. (1982). Metabolic effects of a mixed and a high-carbohydrate low-fat diet in man, measured over $24 \mathrm{~h}$ in a respiration chamber. British Journal of Nutrition 47, 33-43.

INRA (1984). L'alimentation des animaux monogastriques (porc, lapin, volailles) (Feeding of non-ruminant livestock). Paris: INRA.

Just, A. (1982). The net energy value of balanced diets for growing pigs. Livestock Production Science $\mathbf{8}, 541-555$.

Kinabo, J. L. \& Durnin, J. V. G. A. (1990). Thermic effect of food in man: effect of meal composition, and energy content. British Journal of Nutrition 64, 37-44.

Koong, L. J., Nienaber, J. A., Pekas, J. C. \& Yen, J. T. (1982). Effects of plane of nutrition on organ size and fasting heat production in pigs. Journal of Nutrition 112, 1638-1642.

Lin, P. Y., Romsos, D. R., Vander Tuig, J. G. \& Leveille, G. A. (1979). Maintenance energy requirements, energy retention and heat production of young obese $(\mathrm{ob} / \mathrm{ob})$ and lean mice fed a high-fat or a high-carbohydrate diet. Journal of Nutrition 109, 1143-1153.

Nair, K. S., Halliday, D. \& Garrow, J. S. (1983). Thermic response to isoenergetic protein, carbohydrate or fat meals in lean and obese subjects. Clinical Science 65, 307-312.

Noblet, J., Dourmad, J. Y. \& Etienne, M. (1990). Energy utilization in pregnant and lactating sows: Modeling of energy requirements. Journal of Animal Science 68, 562-572.

Noblet, J., Fortune, H., Dubois, S. \& Henry, Y. (1989). Nouvelles bases destimation des teneurs en énergie 
digestible, métabolisable et nette des aliments pour le porc. (New approaches for estimating digestible, metabolizable and net energy values in pig feeds). Paris: INRA.

Noblet, J., Henry, Y.\& Dubois, S. (1987). Effect of protein and lysine levels in the diet on body gain composition and energy utilization in growing pigs. Journal of Animal Science 65, 717-726.

Noblet, J. \& Shi, X. S. (1993). Comparative digestibility of energy and nutrients in growing pigs fed ad libitum and adult sows fed at maintenance. Livestock Production Science 34, 137-152.

Noblet, J., Shi, X. S. \& Dubois, S. (1993). Energy cost of standing activity in sows. Livestock Production Science 34, $127-136$.

Perez, J. M. (1991). Intérêt et limites des modèles de prévision de la valeur énergétique des aliments destinés au porc (Interest and limits of models for prediction of the energy value of pig feeds). Thèse Doctorat, Université Montpellier II.

SAS (1988). SAS User's Guide: Statistics. Cary, NC: SAS Inst.

Schiemann, R., Nehring, K., Hoffmann, L., Jentsch, W. \& Chudy, A. (1972). Energetische Futterbewertung und Energienormen (Food energy evaluation and energy requirements). Berlin: VEB Deutscher Landwirtschaftsverlag.

Schutz, Y., Bessard, T. \& Jequier, E. (1984). Diet-induced thermogenesis measured over a whole day in obese and nonobese women. American Journal of Clinical Nutrition 40, 542-552.

Shi, X. S. \& Noblet, J. (1993). Contribution of the hindgut to digestion of diets in growing pigs and adult sows: effect of diet composition. Livestock Production Science (In the Press.)

Van Es, A. J. H., Vogt, J. E., Niessen, Ch., Veth, H., Rodenburg, L., Teeuwse, V. \& Dhuyvetter, J. (1984). Human energy metabolism below, near and above energy equilibrium. British Joumal of Nutrition 52, 429-442.

Van Soest, P. J. \& Wine, R. H. (1967). Use of detergents in the analysis of fibrous feeds. Determination of plant cell-wall constituents. Journal of Association of Official Analytical Chemistry 50, 50-55.

Vermorel, M., Bouvier, J. C., Binnet, M. \& Fauconneau, G. (1973). Construction et fonctionnement de 2 chambres respiratoires de type circuit ouvert pour jeunes bovins (Construction and operation of two "opencircuit" respiration chambers for young cattle). Annales de Biologie Animale, Biochimie et Biophysique 13, $569-581$. 